\title{
The Spectrum of Threats of Regional Economic Security
}

\author{
Alexander Khorev \\ Economic Security and Financial Monitoring Department \\ Voronezh state university of engineering technologies \\ Voronezh, Russia
}

\author{
Viktoriia Grigorieva \\ Economic Security and Financial Monitoring Department \\ Voronezh state university of engineering technologies \\ Voronezh, Russia
}

\author{
Galina Belyaeva \\ Department of Theory of Economics and Accounting Policy \\ Voronezh state university of engineering technologies \\ Voronezh, Russia \\ al.khorev@gmail.com
}

\begin{abstract}
Indicators for assessing the level of economic security of the region provide an opportunity for a comprehensive assessment of the development and stability of the territory, its ability to withstand the influence of negative external and internal factors. Studies show that there is currently no generally accepted method of assessing the level of economic security. Comparison of actual values of indicators with threshold allows to judge dynamics of change of levels of components of economic security of regions and to carry out a comparative assessment of these components. Definition and calculation of the integral indicator of economic security of the regions comprising the Central Black Earth Economic Region, is proposed by an original technique, allowing to assess the dynamics of changes in the economic security in general, and to determine the spectrum of threats at various components. The integral normalized indicator gives an idea of some boundary between the state of security and the state of insecurity of the region from external and internal threats and allows to visually compare the state of the regions among themselves.
\end{abstract}

Keywords: economic security, Central Black Earth Economic Region, integral indicator of economic security of the regions, spectrum of threats

\section{INTRODUCTION}

The Central Black Earth Economic Region (CBEER) is one of 12 economic regions located in the European part of the Russian Federation. The Central Black Earth Economic Region includes five industrial and agricultural regions: Voronezh, Belgorod, Lipetsk, Kursk and Tambov.

In 2017, the total population of the CBEER was 7206.7 thousand people, an area of 167.7 thousand $\mathrm{km} 2$. District population density is one of the leading in Russia.
The advantage of the location and the provision of important resources is successfully complemented by a developed transport infrastructure and the powerful industrial, ferrous metallurgy, machine-building and electric power, as well as high agricultural potential.

The level of economic security of the region can be characterized by certain quantitative and qualitative criteria, which may reflect the political, economic and social stability and the stability of the region as well as its ability to withstand internal and external threats.

During the last two decades, numerous practical assessments of the levels of economic security of the regions have been carried out [1-12]. In the study, we used the most common and frequently used indicators.

The determination of threshold levels of indicators of economic security of regions is a separate scientific task. Various authors offer their own versions of these values. To determine the economic security indicators of the CBEER, the threshold levels established by the expert assessment method were used. Of course, that was on the threshold levels of economic security indicators values will ultimately depend on the values of the relevant indicators

\section{RESEARCH METHODS}

To determine the level of economic security, we propose a comparison of actual values with the corresponding threshold. It is assumed that the level $\left(\mathrm{y}_{\mathrm{i}}\right)$ can take a value in the interval $[-1 ; 1]$, where $\mathrm{Y}_{\mathrm{i}}=1$ implies the highest level of security for the regional economy, absolute security, maximum strength in this aspect, and $Y_{i}=-1$ means the lowest level of economic security, its maximum risk in this area. When $Y_{i}=0$, we will talk about the borderline value of economic security; it arises 
TABLE II. GROSS REGIONAL PRODUCT PER CAPITA actual value and is critical.

The proposed methodology for calculating the level of economic security will be different for the indicators in which the threshold values are the maximum (in the tables marked with "no more") and minimal (in the tables marked with "at least"). Further, the order of calculation will also be different according to the actual parameter at a threshold or discrepancy. Formulas for determining the level of economic security are presented in the Table I.

TABLE I. DETERMINING THE LEVEL OF ECONOMIC SECURITY

\begin{tabular}{|l|l|l|}
\hline & \multicolumn{1}{|c|}{$\begin{array}{c}\text { Threshold value } \\
\text { "at least" }\end{array}$} & \multicolumn{1}{|c|}{$\begin{array}{c}\text { Threshold value } \\
\text { "no more" }\end{array}$} \\
\hline $\begin{array}{l}\text { The actual value } \\
\text { corresponds to the } \\
\text { threshold }\end{array}$ & $\begin{array}{l}\mathrm{Y}_{\mathrm{i}}=1-\quad \text { (threshold } \\
\text { value) / (actual value) }\end{array}$ & $\begin{array}{l}\mathrm{Y}_{\mathrm{i}}=1 \text { - (actual value) / } \\
\text { (threshold value) }\end{array}$ \\
\hline $\begin{array}{l}\text { Actual value } \\
\text { does not match } \\
\text { threshold }\end{array}$ & $\begin{array}{l}\mathrm{Y}_{\mathrm{i}}=\text { (actual value) / } \\
\text { (threshold value) - 1 }\end{array}$ & $\begin{array}{l}\mathrm{Y}_{\mathrm{i}}=\text { (threshold value) / } \\
\text { (actual value) - 1 }\end{array}$ \\
\hline
\end{tabular}

Estimates of the integral level of economic security is a simple arithmetic average of the values of particular indicators that characterize the various aspects of the economic security of the region:

$$
y_{j}=\frac{\sum_{i=1}^{n} y_{i}}{n}
$$

$\mathrm{Yj}$ - integral index of economic security of the $\mathrm{j}$-th region; $\mathrm{Yi}$ - i-th partial indicator of the economic security of the $\mathrm{j}$-th region; $\mathrm{n}$ - is the number of indicators in the calculation.

\section{RESULTS}

The results of the calculation of the values of the economic security indicators of CBEER by components are presented in tables II-XI.

The results of calculating the integral indicator of the level of economic security of the regions are shown in table XII and illustrated in figure 1. The table also determines the rank (place) of the region by its level of economic security.

\begin{tabular}{|l|c|c|c|c|c|c|}
\hline \multirow{2}{*}{ Region } & \multicolumn{3}{|c|}{ Indicator value, rubles } & \multicolumn{3}{c|}{$\begin{array}{c}\text { Level of } \\
\text { economic } \\
\text { security }\end{array}$} \\
\cline { 2 - 7 } & 2015 & 2016 & 2017 & 2015 & 2016 & 2017 \\
\hline $\begin{array}{l}\text { Threshol } \\
\text { d values } \\
\text { (national } \\
\text { average) }\end{array}$ & 449098 & 472050 & 510253 & - & - & - \\
\hline $\begin{array}{l}\text { Belgorod } \\
\text { region }\end{array}$ & 447620 & 469922 & 506421 & -0.003 & -0.005 & -0.008 \\
\hline $\begin{array}{l}\text { Voronezh } \\
\text { region }\end{array}$ & 345567 & 350098 & 370610 & -0.231 & -0.258 & -0.274 \\
\hline $\begin{array}{l}\text { Kursk } \\
\text { region }\end{array}$ & 301243 & 323149 & 346340 & -0.329 & -0.315 & -0.321 \\
\hline $\begin{array}{l}\text { Lipetsk } \\
\text { region }\end{array}$ & 388075 & 418328 & 431821 & -0.136 & -0.114 & -0.154 \\
\hline $\begin{array}{l}\text { Tambov } \\
\text { region }\end{array}$ & 300290 & 284834 & 289847 & -0.331 & -0.397 & -0.432 \\
\hline $\begin{array}{l}\text { CBEER } \\
\text { average }\end{array}$ & 356559 & 369266 & 389008 & -0.21 & -0.22 & -0.24 \\
\hline \begin{tabular}{l} 
a www.gks.ru \\
\hline
\end{tabular} & & & & & \\
\hline
\end{tabular}

TABLE III. FIXED INVESTMENT

\begin{tabular}{|l|l|l|l|l|l|l|}
\hline \multirow{2}{*}{ Region } & \multicolumn{3}{|c|}{ Indicator value, \%a } & \multicolumn{3}{c|}{$\begin{array}{c}\text { Level of } \\
\text { economic } \\
\text { security }\end{array}$} \\
\cline { 2 - 7 } & $\mathbf{2 0 1 5}$ & $\mathbf{2 0 1 6}$ & $\mathbf{2 0 1 7}$ & $\mathbf{2 0 1 5}$ & $\mathbf{2 0 1 6}$ & $\mathbf{2 0 1 7}$ \\
\hline $\begin{array}{l}\text { Threshold } \\
\text { values }\end{array}$ & 20 & 20 & 20 & - & - & - \\
\hline $\begin{array}{l}\text { Belgorod } \\
\text { region }\end{array}$ & 19.62 & 18.34 & 16.29 & -0.02 & -0.08 & -0.19 \\
\hline $\begin{array}{l}\text { Voronezh } \\
\text { region }\end{array}$ & 26.26 & 28.57 & 29.46 & 0.24 & 0.30 & 0.32 \\
\hline $\begin{array}{l}\text { Kursk } \\
\text { region }\end{array}$ & 20.62 & 23.26 & 22.72 & 0.03 & 0.14 & 0.12 \\
\hline $\begin{array}{l}\text { Lipetsk } \\
\text { region }\end{array}$ & 24.14 & 25.16 & 26.98 & 0.17 & 0.21 & 0.26 \\
\hline $\begin{array}{l}\text { Tambov } \\
\text { region }\end{array}$ & 33.29 & 31.32 & 30.68 & 0.40 & 0.36 & 0.35 \\
\hline $\begin{array}{l}\text { CBEER } \\
\text { average }\end{array}$ & 24.79 & 25.33 & 25.23 & 0.16 & 0.18 & 0.17 \\
\hline \begin{tabular}{l} 
a www.gks.ru \\
\hline
\end{tabular} & & & & & \\
\hline
\end{tabular}


TABLE VI. THE SHARE OF UNPROFITABLE ENTERPRISES

\begin{tabular}{|l|l|l|l|l|l|l|}
\hline \multirow{2}{*}{ Region } & \multicolumn{3}{|c|}{ Indicator value, \% a } & \multicolumn{3}{c|}{$\begin{array}{c}\text { Level of } \\
\text { economic } \\
\text { security }\end{array}$} \\
\cline { 2 - 7 } & \multicolumn{1}{|c|}{2015} & 2016 & 2017 & 2015 & 2016 & 2017 \\
\hline $\begin{array}{l}\text { Threshold } \\
\text { values } \\
\text { (national } \\
\text { average) }\end{array}$ & 32.6 & 29.5 & 31.9 & - & - & - \\
\hline $\begin{array}{l}\text { Belgorod } \\
\text { region }\end{array}$ & 27.1 & 27.3 & 27.8 & 0.17 & 0.07 & 0.13 \\
\hline $\begin{array}{l}\text { Voronezh } \\
\text { region }\end{array}$ & 24.9 & 25.4 & 26.4 & 0.24 & 0.14 & 0.17 \\
\hline $\begin{array}{l}\text { Kursk } \\
\text { region }\end{array}$ & 29.7 & 27.5 & 31.5 & 0.09 & 0.07 & 0.01 \\
\hline $\begin{array}{l}\text { Lipetsk } \\
\text { region }\end{array}$ & 25.5 & 25.6 & 30.5 & 0.22 & 0.13 & 0.04 \\
\hline $\begin{array}{l}\text { Tambov } \\
\text { region }\end{array}$ & 25.4 & 25.1 & 29.6 & 0.22 & 0.15 & 0.07 \\
\hline $\begin{array}{l}\text { CBEER } \\
\text { average }\end{array}$ & 26.52 & 26.18 & 29.16 & 0.19 & 0.11 & 0.09 \\
\hline \begin{tabular}{l} 
a www.gks.ru \\
\hline
\end{tabular} & & & & & \\
\hline
\end{tabular}

TABLE V. THE VOLUME OF INNOVATIVE PRODUCTS, WORKS AND SERVICES AS A PERCENTAGE OF THE TOTAL VOLUME OF GOODS, WORKS, SERVICES

\begin{tabular}{|c|c|c|c|c|c|c|}
\hline \multirow[t]{2}{*}{ Region } & \multicolumn{3}{|c|}{ Indicator values, $\%^{a}$} & \multicolumn{3}{|c|}{$\begin{array}{c}\text { Level of } \\
\text { economic } \\
\text { security }\end{array}$} \\
\hline & 2015 & 2016 & 2017 & 2015 & 2016 & 2017 \\
\hline $\begin{array}{l}\text { Threshold } \\
\text { values }\end{array}$ & 8.4 & 8.5 & 7.2 & - & - & - \\
\hline $\begin{array}{l}\text { Belgorod } \\
\text { region }\end{array}$ & 5 & 7.3 & 11.6 & -0.40 & -0.14 & 0.38 \\
\hline $\begin{array}{l}\text { Voronezh } \\
\text { region }\end{array}$ & 12.4 & 5.9 & 6.1 & 0.32 & -0.31 & -0.15 \\
\hline $\begin{array}{l}\text { Kursk } \\
\text { region }\end{array}$ & 6.2 & 7.6 & 8.4 & -0.26 & -0.11 & 0.14 \\
\hline $\begin{array}{l}\text { Lipetsk } \\
\text { region }\end{array}$ & 12.3 & 10.5 & 9.3 & 0.32 & 0.19 & 0.23 \\
\hline $\begin{array}{l}\text { Tambov } \\
\text { region }\end{array}$ & 6.1 & 4.5 & 7.9 & -0.27 & -0.47 & 0.09 \\
\hline $\begin{array}{l}\text { CBEER } \\
\text { average }\end{array}$ & 8.4 & 7.16 & 8.66 & -0.06 & -0.17 & 0.14 \\
\hline
\end{tabular}

TABLE VII. UNEMPLOYMENT RATE

\begin{tabular}{|l|l|l|l|l|l|l|}
\hline \multirow{2}{*}{ Region } & \multicolumn{3}{|c|}{ Indicator value, \% a } & \multicolumn{3}{c|}{$\begin{array}{c}\text { Level of } \\
\text { economic } \\
\text { security }\end{array}$} \\
\cline { 2 - 7 } & \multicolumn{1}{|c|}{2015} & \multicolumn{1}{|c|}{2016} & 2017 & 2015 & 2016 & 2017 \\
\hline $\begin{array}{l}\text { Threshold } \\
\text { value }\end{array}$ & 5 & 5 & 5 & - & - & - \\
\hline $\begin{array}{l}\text { Belgorod } \\
\text { region }\end{array}$ & 4.1 & 4 & 3.9 & 0.18 & 0.2 & 0.22 \\
\hline $\begin{array}{l}\text { Voronezh } \\
\text { region }\end{array}$ & 4.5 & 4.5 & 4.3 & 0.1 & 0.1 & 0.14 \\
\hline $\begin{array}{l}\text { Kursk } \\
\text { region }\end{array}$ & 4.2 & 4.3 & 4.1 & 0.16 & 0.14 & 0.18 \\
\hline $\begin{array}{l}\text { Lipetsk } \\
\text { region }\end{array}$ & 4.1 & 4 & 3.9 & 0.18 & 0.2 & 0.22 \\
\hline $\begin{array}{l}\text { Tambov } \\
\text { region }\end{array}$ & 4.6 & 4.5 & 4.4 & 0.08 & 0.1 & 0.12 \\
\hline $\begin{array}{l}\text { CBEER } \\
\text { average }\end{array}$ & 4.3 & 4.26 & 4.12 & 0.14 & 0.15 & 0.18 \\
\hline \begin{tabular}{l} 
a www.gks.ru \\
\hline
\end{tabular} & & & & & \\
\hline
\end{tabular}


TABLE X. CONSUMER PRICE INDEX

\begin{tabular}{|l|l|l|l|l|l|l|}
\hline \multirow{2}{*}{ Region } & \multicolumn{3}{|c|}{ Indicator value, \% } & \multicolumn{3}{c|}{$\begin{array}{c}\text { Level of } \\
\text { economic } \\
\text { security }\end{array}$} \\
\cline { 2 - 7 } & $\mathbf{2 0 1 5}$ & $\mathbf{2 0 1 6}$ & $\mathbf{2 0 1 7}$ & $\mathbf{2 0 1 5}$ & $\mathbf{2 0 1 6}$ & $\mathbf{2 0 1 7}$ \\
\hline $\begin{array}{l}\text { Threshold } \\
\text { value }\end{array}$ & 350 & 350 & 350 & - & - & - \\
\hline $\begin{array}{l}\text { Belgorod } \\
\text { region }\end{array}$ & 414.2 & 408.2 & 395 & 0.15 & 0.14 & 0.11 \\
\hline $\begin{array}{l}\text { Voronezh } \\
\text { region }\end{array}$ & 437.7 & 407.4 & 402.3 & 0.20 & 0.14 & 0.13 \\
\hline $\begin{array}{l}\text { Kursk } \\
\text { region }\end{array}$ & 429.8 & 352.7 & 358.7 & 0.19 & 0.01 & 0.02 \\
\hline $\begin{array}{l}\text { Lipetsk } \\
\text { region }\end{array}$ & 423.4 & 386.5 & 388.1 & 0.17 & 0.09 & 0.10 \\
\hline $\begin{array}{l}\text { Tambov } \\
\text { region }\end{array}$ & 400.5 & 371.7 & 366.2 & 0.13 & 0.06 & 0.04 \\
\hline $\begin{array}{l}\text { CBEER } \\
\text { average }\end{array}$ & 421.12 & 385.3 & 382.06 & 0.17 & 0.09 & 0.08 \\
\hline www.gks.ru & & & & & \\
\hline
\end{tabular}

TABLE IX. THE POPULATION WITH CASH INCOMES BELOW THE SUBSISTENCE LEVEL (OF THE TOTAL POPULATION)

\begin{tabular}{|l|l|l|l|l|l|l|}
\hline \multirow{2}{*}{ Region } & \multicolumn{3}{|c|}{ Indicator value, \% a } & \multicolumn{3}{c|}{$\begin{array}{c}\text { Level of } \\
\text { economic } \\
\text { security }\end{array}$} \\
\cline { 2 - 8 } & $\mathbf{2 0 1 5}$ & $\mathbf{2 0 1 6}$ & $\mathbf{2 0 1 7}$ & $\mathbf{2 0 1 5}$ & $\mathbf{2 0 1 6}$ & $\mathbf{2 0 1 7}$ \\
\hline $\begin{array}{l}\text { Threshold } \\
\text { value }\end{array}$ & 7 & 7 & 7 & - & - & - \\
\hline $\begin{array}{l}\text { Belgorod } \\
\text { region }\end{array}$ & 8.5 & 8.2 & 7.9 & -0.18 & -0.15 & -0.11 \\
\hline $\begin{array}{l}\text { Voronezh } \\
\text { region }\end{array}$ & 9.3 & 9.3 & 9.1 & -0.25 & -0.25 & -0.23 \\
\hline $\begin{array}{l}\text { Kursk } \\
\text { region }\end{array}$ & 10.2 & 10.3 & 10.2 & -0.31 & -0.32 & -0.31 \\
\hline $\begin{array}{l}\text { Lipetsk } \\
\text { region }\end{array}$ & 9.1 & 9 & 8.8 & -0.23 & -0.22 & -0.20 \\
\hline $\begin{array}{l}\text { Tambov } \\
\text { region }\end{array}$ & 10.7 & 10.6 & 10.5 & -0.35 & -0.34 & -0.33 \\
\hline $\begin{array}{l}\text { CBEER } \\
\text { average }\end{array}$ & 9.56 & 9.48 & 9.3 & -0.26 & -0.26 & -0.24 \\
\hline awww.gks.ru & & & & & \\
\hline
\end{tabular}

TABLE XI. FUND RATIO

\begin{tabular}{|l|l|l|l|l|l|l|}
\hline \multirow{2}{*}{ Region } & \multicolumn{3}{|c|}{ Indicator value, \% a } & \multicolumn{3}{c|}{$\begin{array}{c}\text { Level of } \\
\text { economic } \\
\text { security }\end{array}$} \\
\cline { 2 - 7 } & 2015 & 2016 & 2017 & 2015 & $\mathbf{2 0 1 6}$ & $\mathbf{2 0 1 7}$ \\
\hline $\begin{array}{l}\text { Threshold } \\
\text { values } \\
\text { (national } \\
\text { average) }\end{array}$ & 112.9 & 105.4 & 102.5 & - & - & - \\
\hline $\begin{array}{l}\text { Belgorod } \\
\text { region }\end{array}$ & 111.4 & 104.4 & 101.5 & 0.013 & 0.009 & 0.010 \\
\hline $\begin{array}{l}\text { Voronezh } \\
\text { region }\end{array}$ & 113.6 & 105.5 & 101.5 & -0.006 & -0.001 & 0.010 \\
\hline $\begin{array}{l}\text { Kursk } \\
\text { region }\end{array}$ & 113.9 & 105.8 & 102.1 & -0.009 & -0.004 & 0.004 \\
\hline $\begin{array}{l}\text { Lipetsk } \\
\text { region }\end{array}$ & 112.1 & 104.6 & 102.3 & 0.007 & 0.008 & 0.002 \\
\hline $\begin{array}{l}\text { Tambov } \\
\text { region }\end{array}$ & 112.7 & 105.2 & 102 & 0.002 & 0.002 & 0.005 \\
\hline $\begin{array}{l}\text { CBEER } \\
\text { average }\end{array}$ & 112.74 & 105.1 & 101.88 & 0.001 & 0.003 & 0.006 \\
\hline awww.gks.ru & & & & & \\
\hline
\end{tabular}

\begin{tabular}{|l|l|l|l|l|l|l|}
\hline \multirow{2}{*}{ Region } & \multicolumn{3}{|c|}{ Indicator value, \% a } & \multicolumn{3}{c|}{$\begin{array}{c}\text { Level of } \\
\text { economic } \\
\text { security }\end{array}$} \\
\cline { 2 - 8 } & $\mathbf{2 0 1 5}$ & $\mathbf{2 0 1 6}$ & $\mathbf{2 0 1 7}$ & $\mathbf{2 0 1 5}$ & $\mathbf{2 0 1 6}$ & $\mathbf{2 0 1 7}$ \\
\hline $\begin{array}{l}\text { Threshold } \\
\text { value }\end{array}$ & 8 & 8 & 8 & - & - & - \\
\hline $\begin{array}{l}\text { Belgorod } \\
\text { region }\end{array}$ & 13.3 & 13.9 & 13.6 & -0.40 & -0.42 & -0.41 \\
\hline $\begin{array}{l}\text { Voronezh } \\
\text { region }\end{array}$ & 15.5 & 15.1 & 14.1 & -0.48 & -0.47 & -0.43 \\
\hline $\begin{array}{l}\text { Kursk } \\
\text { region }\end{array}$ & 12.4 & 12.4 & 11.8 & -0.35 & -0.35 & -0.32 \\
\hline $\begin{array}{l}\text { Lipetsk } \\
\text { region }\end{array}$ & 13.1 & 13.2 & 13.2 & -0.39 & -0.39 & -0.39 \\
\hline $\begin{array}{l}\text { Tambov } \\
\text { region }\end{array}$ & 12.6 & 12.8 & 12.3 & -0.37 & -0.38 & -0.35 \\
\hline $\begin{array}{l}\text { CBEER } \\
\text { average }\end{array}$ & 13.38 & 13.48 & 13 & -0.40 & -0.40 & -0.38 \\
\hline www.gks.ru & & & & & \\
\hline
\end{tabular}

TABLE XII. LEVEL OF ECONOMIC SECURITY

\begin{tabular}{|l|l|l|l|l|l|l|}
\hline \multirow{2}{*}{ Region } & \multicolumn{3}{|c|}{ Indicator value } & \multicolumn{3}{c|}{ Range } \\
\cline { 2 - 7 } & $\mathbf{2 0 1 5}$ & $\mathbf{2 0 1 6}$ & $\mathbf{2 0 1 7}$ & $\mathbf{2 0 1 5}$ & $\mathbf{2 0 1 6}$ & $\mathbf{2 0 1 7}$ \\
\hline $\begin{array}{l}\text { Belgorod } \\
\text { region }\end{array}$ & -0.045 & -0.038 & 0.012 & 3 & 2 & 2 \\
\hline $\begin{array}{l}\text { Voronezh } \\
\text { region }\end{array}$ & 0.029 & -0.047 & -0.013 & 1 & 3 & 3 \\
\hline $\begin{array}{l}\text { Kursk } \\
\text { region }\end{array}$ & -0.083 & -0.074 & -0.050 & 5 & 4 & 4 \\
\hline $\begin{array}{l}\text { Lipetsk } \\
\text { region }\end{array}$ & 0.025 & -0.003 & -0.005 & 2 & 1 & 1 \\
\hline $\begin{array}{l}\text { Tambov } \\
\text { region }\end{array}$ & -0.054 & -0.102 & -0.057 & 4 & 5 & 5 \\
\hline $\begin{array}{l}\text { CBEER } \\
\text { average }\end{array}$ & -0.025 & -0.053 & -0.023 & - & - & - \\
\hline
\end{tabular}




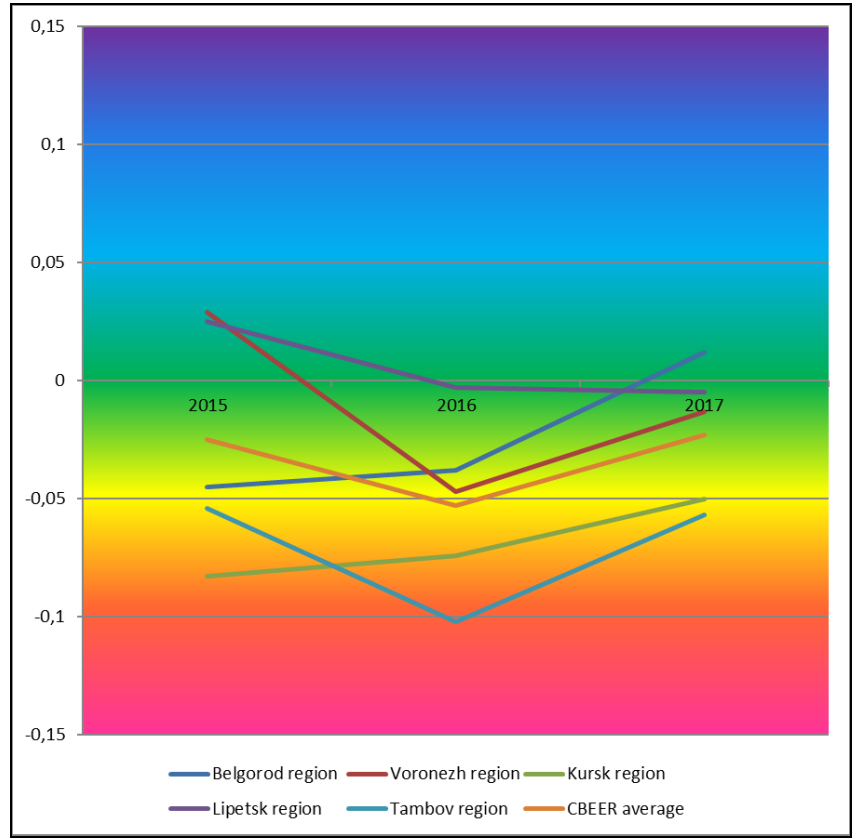

Fig. 1. The spectrum of threats of regional economic security

In the figure, security zones are presented in the form of a spectrum that changes its color from red to violet. If the integral indicator falls into the green zone, this means that the region is in a borderline state to the security aspect. The yellow zone means a significant threat to economic security, the red zone catastrophically requires the attention of the authorities. And vice versa, the blue zone means a certain margin of safety, the blue one means the average level, and the violet one means the complete absence of risk at the moment. Each zone may have its own set of actions, depending on the specifics of the indicator or region.

\section{DISCUSSION}

In our calculations, we used the most well-known indicators, such as the following.

An aggregated indicator of the economic activity of a particular region is the gross regional product (GRP), which characterizes the process of production of goods and services for final use $[13 ; 14]$. The more successfully a particular region develops, the higher the value of this indicator will be, providing positive dynamics for the development of not only the trade and economic, but also the social sphere.

An analysis of the causes of unemployment is an important tool for the formation of programs and measures aimed at ensuring the employment $[15 ; 16]$. It is an effective activity of the working population provides a sustainable economic growth of the region.

The ability of the population to provide themselves with basic necessities, food, payment of bills, etc., depends on the level of nominal wages. The higher the level of wages in the region, the more citizens tend to enter its territory to get a job, thereby developing the labour market $[17 ; 18]$.
One of the most important indicators to assess the prospects for the development of the region is the volume of investment in fixed assets. As practice shows, investment resources are a priority factor for the development of real production, trade, business and social infrastructure $[19 ; 20]$. The greater the investment potential a certain region possesses, the better the material base and development of the transport network, the administrative apparatus of the region works better in matters of strategic cooperation with large business, and the quality and qualification of labour resources are higher.

The number of indicators can be extended, which will more accurately determine the level of economic security.

\section{CONCLUSION}

In our opinion, the obtained values of integral indicators of economic security of the regions of the CBEER reflect the phenomena and processes that have occurred in the economy of these regions. The proposed method of assessing the level of economic security has a number of advantages:

- it allows to bring absolute values of indicators to the normalized values by means of which it is possible to compare level of safety on different regions among themselves;

- indicators clearly reflect the level of security or insecurity on the component;

- the mathematical apparatus of the technique is accessible and has simplicity and clarity of calculation and interpretation.

Thus, the presented approach to the assessment of the level of economic security of the regions gives, on the one hand, the opportunity to assess the dynamics of changes in the economic security of the region as a whole, and on the other - to compare the levels of security of different regions among themselves.

\section{REFERENCES}

[1] D. V. Gordienko, "Possible approach towards the evaluation of level of economic security of state", State and Law, Russian Academy of Sciences, 2007, vol. 9, pp. 110-112.

[2] N. A. Kazakova and et al., "Monitoring economic security in the region based on indicators of sustainable developmen", Studies on Russian Economic Development, 2016, vol. 27.6, pp. 638-648.

[3] V. Lokosov, Yel. Ryumina, and V. Ulyanov, "Regional differentiation of human potential indicators", Economy of region, 2015, vol. 1.4, pp. 185-196.

[4] Yu. Lysenko, J. Zelenskaya, "System performance indicators of regional economic securit", SHS Web of Conferences, EDP Sciences, 2017, vol. 35.

[5] E. Karanina and D. Loginov, "Indicators of economic security of the region: a risk-based approach to assessing and rating", IOP Conference Series: Earth and Environmental Science, IOP Publishing, 2017, vol. 90, no. 1 .

[6] I. V Chistnikova and et al., "Indicators and a mechanism to ensure economic security of the region", Regional Science Inquiry, 2017, vol. IX, (1), pp. 97-105. 
[14] A. Ponomarenko, "Gross Regional Product for Russian regions: compilation methods and preliminary results", 2000.

[7] Yu. N. Vorobyov and et al., "Sustainable Development of the Regional Economy: Indicators, Analysis, Systematization", Journal of Advanced Research in Law and Economics, 2018, vol. 9.2 (32), pp. 729-739.

[8] S. Beliakov and A. Kapustkina, "Analysis of performance indicators of functioning of territories with special economic status in the Russian Federation", Procedia engineering, 2016, vol. 165, pp. 1424-1429.

[9] G. Capannelli, Jong-Wha Lee, and P. A. Petri, "Developing indicators for regional economic integration and cooperation", Singapore Economic Review, Forthcoming, 2009.

[10] F. Jany-Catrice and G. Marlier, "Regional indicators of well-being: The case of france", Community Quality-of-Life Indicators: Best Cases VI. Springer, Dordrecht, 2013, pp. 19-44.

[11] K. K. Loginov, "Analysis of indicators of regional economic security", Vestnik Sibirskoi gosudarstvennoi avtomobil'no-dorozhnoi akademii, Bulletin of Siberian State Automobile and Highway Academy, 2015, vol. 2, pp. 132-139.

[12] S. Oguz and J. Knight, "Regional Economic Indicators: with a focus on sub-regional Gross Valued Added using shift-share analysis", Economic and Labour Market Review, 2010, vol. 4.11, pp. 64-105.

[13] Vu Quang Viet, "Gross regional product (GRP): an introduction", International Workshop: Regional Products and Income Accounts, Beijing, China, 2010.
[15] P. Epifani and Gino A. Gancia, "Trade, migration and regional unemployment", Regional Science and Urban Economics, 2005, vol. 35.6, pp. 625-644.

[16] V. Gimpelson, R. Kapelyushnikov, and A. Lukyanova, "Employment protection legislation in Russia: regional enforcement and labor market outcomes", Comparative Economic Studie, 2010, vol. 52.4, pp. 611636.

[17] A. Oshchepkov, "Compensating wage differentials across Russian regions", Geographical Labor Market Imbalances, Springer, Berlin, Heidelberg, 2015, pp. 65-105.

[18] C. Ogloblin and G. Brock, "Wage determination in urban Russia: Underpayment and the gender differential", Economic Systems, 2005, vol. 29.3, pp. 325-343.

[19] O. Izryadnova, "Investments in fixed assets", Russian Economic Developments, January 24, 2013, no. 1.

[20] Yu A. Gadzhiev, V. I. Akopov, and T. S. Krestovskikh, "Economy of Russia's Northern regions: Investment in fixed assets", Studies on Russian Economic Development, 2012, no. 23.5, pp. 488-498. 